\title{
SINTESIS KARBON AKTIF BERBAHAN DASAR MIKROALGA CHLORELLA VULGARIS BERBANTUKAN IRADIASI GELOMBANG MIKRO MENGGUNAKAN AKTIVATOR KOH
}

\author{
Agung Sukoyo \\ Program Magister Keteknikan Pertanian \\ Fakultas Teknologi Pertanian \\ Universitas Brawijaya \\ Jalan Veteran No. 1 Malang 65145 \\ ohmagung@gmail.com

\section{Gunomo Djoyowasito} \\ Program Studi Keteknikan Pertanian \\ Fakultas Teknologi Pertanian \\ Universitas Brawijaya \\ Jalan Veteran No. 1 Malang 65145 \\ djoyowasitogunomo@yahoo.com \\ Yusuf Wibisono \\ Program Studi Teknik Bioproses \\ Fakultas Teknologi Pertanian \\ Universitas Brawijaya \\ Jalan Veteran No. 1 Malang 65145 \\ Email:Y_Wibisono@ub.ac.id
}

Microalgae Chlorella vulgaris has been used as a raw material in the synthesis of powdered activated carbon. Dry microalgae was pyrolyzed at a temperature of $500^{\circ} \mathrm{C}$ for 30 minutes to obtain microalgae charcoal. The combination of chemical activation treatment using $\mathrm{KOH}$ with concentrations of 10, 30, and 50\% assisted by microwave irradiation have been used to prepare activated carbon. The properties of activated carbon were analyzed included yield, ash content, volatile substance content, pure activated carbon content, iodine solution absorbency, BET surface area and activated carbon imaging using SEM EDX. The results showed that Chlorella vulgaris microalgae has a carbon element content of $16.09 \%$ which has the potential to be used as an activated carbon feedstock. The microalgae activated carbon produced has a range of yield of $27.60-48.64 \%$, ash content $27.98-44.23 \%$, volatile substance content $23.08-30.92 \%$, pure activated carbon content $32.69-41.10 \%$, absorption of iodine solution $189.46-260.23 \mathrm{mg} / \mathrm{g}$, surface area BET was obtained at $34,933 \mathrm{~m}^{2} / \mathrm{g}$, with a pore average of $46.59 \mathrm{~nm}$ in the sample with the highest iodine absorption. Activation using microwave irradiation and higher $\mathrm{KOH}$ concentration, i.e. 50\%, can reduce the yield and an ash content of activated carbon, on the other hand, increase the level of volatile substances and iodine absorption. SEM EDX imaging results show the formation of micropores on the surface of microalgae activated carbon, however the impurities promotes the deterioration of surface area and lowering the absorption performance of microalgae activated carbon.

Keywords : Activated Carbon, Microalgae, Chlorella Vulgaris, Microwave Iradiation, $\mathrm{KOH}$

\section{PENDAHULUAN}

Biomassa telah menjadi sumber penting dalam pembuatan biofuel, bioproduk dan biomaterial yang dipakai dalam berbagai macam keperluan [1]. Transisi untuk kembali ke pemanfaatan sumber daya yang dapat diperbaharui ini disebabkan oleh beberapa faktor, diantaranya penurunan kualitas lingkungan, keamanan nasional, dan hasil produksi pertanian [2]. Berkaitan dengan hal ini, mikroalga telah mendapat banyak perhatian karena organisme fotosintesis mikroskopis ini merupakan sumber biomassa yang menjanjikan dan memiliki beberapa keunggulan dibanding tanaman berbasis lahan. Diantaranya adalah hasil yang lebih tinggi dalam produksi lipid sebagai bahan baku biodiesel dan penyerapan karbon dioksida [3].

Mikroalga adalah organisme fotosintesis yang paling cepat berkembang, selain mengkonsumsi senyawa $\mathrm{CO}_{2}$ dan unsur $\mathrm{N}$ mikroalga juga merupakan salah satu produsen oksigen terpenting di bumi [4]. Bila dibandingkan dengan tanaman terestrial, mikroalga memiliki aktivitas fotosintesis yang lebih tinggi, tingkat pertumbuhan lebih cepat dan efisiensi fiksasi $\mathrm{CO}_{2}$ yang lebih baik, yaitu sekitar 10-50 kali [5]. Mikroalga mengandung hampir 50\% karbon dengan basis berat kering, dan secara teoritis, setiap $1 \mathrm{~kg}$ biomassa alga kering dapat menyerap sekitar 1,83 $\mathrm{kg} \mathrm{CO}_{2}$ [6]. Lebih dari itu, biomassa mikroalga pada 
umumnya mengandung komponen penting seperti protein, lipid, karbohidrat dan mineral. Biomassa mikroalga mengandung proporsi protein yang bervariasi (6-52\%), karbohidrat (5-23\%) dan lipid (7-23\%).

Mengacu pada potensi biomassa mikroalga yang banyak mengandung unsur potensial dan dapat dikembangkan dengan cepat, membuat mikroalga menjadi sumber penting, yang dapat diaplikasikan sebagai bahan makanan, perawatan kesehatan, biofuel, pakan hewan / akuakultur, pigmen, dan kosmetik [7, 8]. Lebih dari itu, penelitian terbaru seputar pemanfaatan biomassa mikroalga juga berfokus pada pemanfaatan biomassa mikroalga untuk produksi biohidrogen, biogas (metana), bio-crude dan biochar dengan proses fermentasi, proses anaerobik, pencairan maupun pirolisis $[9,10,11,12,13]$. Salah satu potensi mikroalga yang belum banyak diteliti adalah dipakai sebagai bahan baku dari karbon aktif. Penelitian tentang pembuatan karbon aktif mikroalga masih jarang ditemukan di berbagai literatur, padahal potensinya sangat besar. Karbon aktif banyak dipergunakan sebagai absorber dalam berbagai keperluan industri, mulai industri kimia, industri otomotif hingga industri pangan. Pemanfaatan karbon aktif berbahan dasar mikroalga dalam industri pangan dan pengolahan air, juga mampu untuk menyediakan absorber yang sehat dan halal [14, 15]. Penelitian ini membahas tentang pembuatan karbon aktif dari biomassa mikroalga Chlorella vulgaris dengan menggunakan metode aktivasi kimia dengan bantuan iradiasi gelombang mikro untuk mengoptimalkan terjadinya pembentukan pori-pori karbon aktif dengan waktu yang lebih singkat dibandingkan dengan aktivasi menggunakan pemanasan konvensional. Mekanisme ini terjadi karena adanya gaya yang terdapat dalam molekul menyebabkan molekul polar tidak bisa mengikuti pola orientasi medan. Peristiwa tersebut memicu terjadinya pergerakan partikel secara acak dan akan menghasilkan panas [16], dimana panas yang dihasilkan akan mampu meretakan dan memicu terjadinya pori-pori pada molekul karbon aktif. Diharapkan, hasil penelitian ini bisa memperbesar pemanfaatan mikroalga yang melimpah ketersediaannya di Indonesia, untuk pemanfaatan sebagai karbon aktif di dunia industri.

\section{METODE DAN BAHAN}

Mikroalga Chlorella vulgaris yang digunakan sebagai bahan baku karbon aktif dalam penelitian ini diperoleh dari Balai Perikanan dan Budidaya Air Payau (BPBAP), Situbondo. Biomassa mikroalga ini merupakan hasil pengembangbiakan dengan menggunakan kolam terbuka selama 7 hari dengan penambahan pupuk walne dengan campuran $\mathrm{KNO}_{3}, \mathrm{NaH}_{2} \mathrm{PO}_{4}, \mathrm{Na}_{2} \mathrm{EDTA}, \mathrm{FeCl}_{3}$ untuk menyediakan kecukupan nutrisi bagi pertumbuhan mikroalga. Biomassa mikroalga dikeringkan dengan menggunakan oven pada suhu $60^{\circ} \mathrm{C}$ selama 8 jam dan dilanjutkan dengan pengeringan menggunakan sinar matahari hingga didapatkan serbuk mikroalga Chlorella vulgaris dengan kadar air $4.47 \%$. Karbonisasi biomassa mikroalga kering dilakukan pada suhu $500^{\circ} \mathrm{C}$ dengan laju pemanasan $10^{\circ} \mathrm{C}$ /menit dan waktu penahanan selama 30 menit. Arang yang dihasilkan dari proses karbonisasi disamakan ukurannya menjadi sekitar $149 \mu \mathrm{m}$ dengan menggunakan kawat mesh. Kemudian, 8 gram sample arang mikrolga direndam dalam $30 \mathrm{ml}$ larutan $\mathrm{KOH}$ dengan konsentrasi masing-masing adalah $10 \%, 30 \%$ dan 50\%. Perendaman dilakukan selama 12 jam, dilanjutkan dengan iradiasi gelombang mikro selama 8 menit dengan menggunakan daya 600 Watt. Setelah proses aktivasi, karbon aktif yang dihasilkan dibersihkan dengan cara dicuci dengan menggunakan $1 \mathrm{M} \mathrm{HCl}$ panas dan pencucian dilanjutkan dengan menggunakan air destilasi sampai didapatkan $\mathrm{pH}$ karbon aktif mendekati 7.0. Karbon aktif yang diperoleh selanjutnya dikeringkan dengan menggunakan oven pada suhu $105^{\circ} \mathrm{C}$ selama 24 jam sampai didapatkan karbon aktif kering. Setiap rangkaian percobaan dalam penelitian diulang sebanyak tiga kali. Hasil yang diperoleh untuk selanjutnya akan dibandingkan dengan arang mikroalga yang tidak dilakukan aktivasi dan karbon aktif komersial berbahan baku tempurung kelapa (Haycarb PLC). Paramater pengamatan yang dianalisis dari penelitian ini meliputi kadar abu, kadar zat teruap, kadar karbon aktif murni, daya serap larutan iodin sesuai dengan standar SNI 1995, luas permukaan BET, struktur pori dan komposisi unsur karbon aktif mikroalga chlorella vulgaris.

\subsection{Pengujian Kadar Abu}

Pengujian kadar abu dilakukan sesuai dengan SNI dengan tahapan sebagai berikut: Sampel karbon aktif diambil pada setiap perlakuan sebanyak 1 gram, kemudian dimasukkan kedalam krus porselen (porcellain crucible) yang telah diketahui massanya. Sampel beserta krus porselen dimasukkan ke dalam tungku pembakaran (furnace) dengan suhu $750^{\circ} \mathrm{C}$ selama $1 \mathrm{jam}$. Krus porselen diambil dan didinginkan, lalu massa sampel akhir ditimbang. Proses pemanasan dengan tungku pembakaran diulang hingga didapatkan berat abu konstan. Nilai kadar abu dihitung dengan Persamaan 1 sebagai berikut:

$$
K a=\frac{m_{0}}{m_{1}} 100 \%
$$

Keterangan :

$\mathrm{Ka}=\mathrm{Kadar}$ abu $(\%)$

$\mathrm{m}_{0}=$ Massa awal (gram) 
$\mathrm{m}_{1}=$ Massa akhir $($ gram $)$

\subsection{Pengujian Kadar Zat Teruap}

Penentuan nilai kadar zat teruap dilakukan sesuai dengan SNI dengan tahapan sebagai berikut: Sampel karbon aktif pada setiap perlakuan diambil sebanyak 1 gram, kemudian dimasukkan ke dalam krus porselen yang telah diketahui massanya. Sampel dipanaskan dengan suhu $950^{\circ} \mathrm{C}$ selama 10 menit dengan menggunakan tungku pembakaran. Krus porselen diambil dan didinginkan, kemudia massa akhir sampel ditimbang. Nilai kadar zat teruap dihitung dengan menggunakan Persamaan 2 sebagai berikut:

$$
K z t=\left[\frac{a-b}{a} \times 100 \%\right]
$$

Keterangan:

Kzt $=$ Kadar Zat Teruap

$\mathrm{a} \quad=$ massa awal sampel sebelum pemanasan (gram)

$\mathrm{b} \quad=$ massa akhir sampel setelah pemanasan (gram).

\subsection{Pengujian Kadar Karbon Aktif Murni}

Perhitungan kadar karbon terikat atau kadar karbon aktif murni merupakan banyaknya karbon hasil dari proses pembakaran tanpa kehadiran zat lain yang terdapat dalam karbon, seperti abu dan zat lain yang masih menempel pada permukaan karbon aktif. Kadar karbon aktif murni dapat dihitung menggunakan Persamaan 3 sebagai berikut:

$$
K k t=100 \%-(K a+K z t)
$$

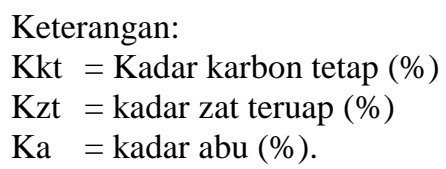

\subsection{Pengujian Daya Serap lodin}

Penentuan nilai daya serap iodin pada penelitian ini sesuai dengan SNI 1995 dan dilakukan dengan tahapan sebagai berikut: Sampel karbon aktif ditimbang sebanyak 0,25 gram kemudian dimasukkan ke dalam tabung erlenmeyer. Larutan Iodin standar 0,1 N ditambahkan sebanyak $25 \mathrm{ml}$. Campuran diaduk selama 15 menit kemudian disaring. Sebanyak10 ml filtrat ini dimasukkan ke dalam erlenmeyer lain, kemudian dilakukan titrasi filtrat dengan natrium tiosulfat $0,1 \mathrm{~N}$ hingga berwarna kuning pucat. Indikator larutan amilum 1\% ditambahkan ke dalamnya dan titrasi diteruskan hingga filtrat menjadi bening. Jumlah larutan Natrium tiosulfat yang terpakai harus tercatat, untuk menghitung nilai daya serap iodin dengan menggunakan Persamaan 4 berikut:

$$
I A N=\left(\frac{10-\left(\frac{B x C}{D}\right) \times 12.693 \times 2.5}{W}\right)
$$

Keterangan:

IAN = Bilangan Iodin ( $\mathrm{mg}$ iodin $/ \mathrm{g}$ karbon aktif)

$\mathrm{B} \quad=$ Volume Natrium tiosulfat total yang terpakai selama titrasi (ml)

$\mathrm{C} \quad=$ Normalitas Natrium tiosulfat $(\mathrm{N})$

$\mathrm{D} \quad=$ Normalitas Iodin $(\mathrm{N})$

$\mathrm{W}=$ Massa Karbon aktif $(\mathrm{g})$

$12,693=$ Jumlah Iodin yang sesuai dengan $1 \mathrm{ml}$ larutan Natrium tiosulfat $0,1 \mathrm{~N}$

\subsection{Pengujian Luas Permukaan BET}

Pengujian luas permukaan BET dilakukan dengan menggunakan Surface Area Analyzer Nova 1200e (Quantachrome Instruments). Alat ini digunakan untuk mengetahui luas permukaan karbon aktif yang dihasilkan secara langsung. Sebelum diukur luas permukaannya, massa sampel ditimbang terlebih dahulu sehingga dapat diketahui luas permukaan setiap satu gram sampel.

\subsection{Pencitraan Pori dan Komposisi Unsur}

Pencitraan pori dan komposisi unsur dilakukan dengan menggunakan alat uji SEM-EDX. Pengujian SEM dilakukan untuk mengetahui pola permukaan dan pori karbon aktif yang terbentuk, sedangkan pengujian EDX dilakukan untuk menganalisis komposisi unsur karbon aktif.

\section{HASIL DAN DISKUSI}




\subsection{Rendemen}

Perhitungan rendemen karbon aktif mikroalga ditujukan untuk mengetahui besarnya rendemen karbon aktif yang dihasilkan pasca aktivasi. Perhitungan rendemen karhon aktif ini dilakukan setelah proses karbonisasi, ketika masih berbentuk mikroalga.

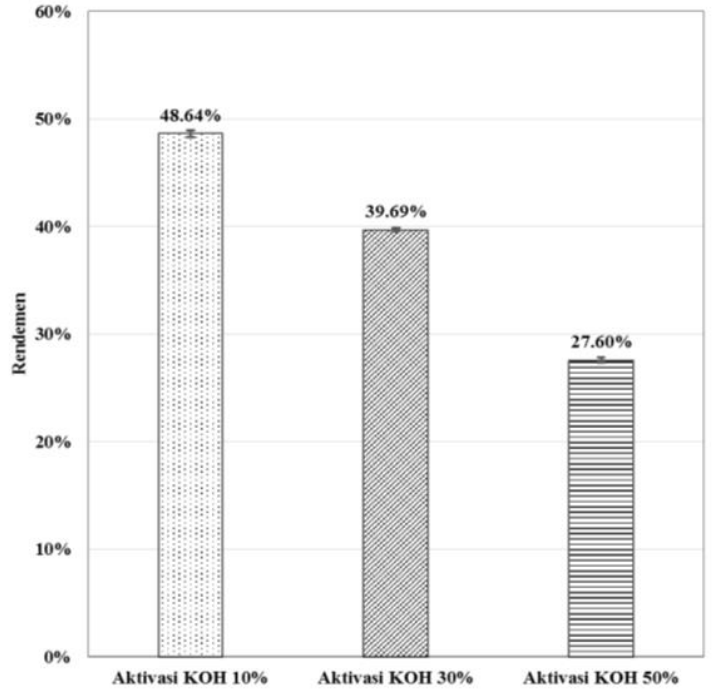
ıgan hasil akhir karbon aktif

Gambar 1. Rendemen karbon aktif mikroalga Chlorella vulgaris menurun dengan peningkatan konsentrasi zat pengaktivasi.

Gambar 1 menunjukan tingkat rendemen yang diperoleh pasca aktivasi arang mikroalga Chlorella vulgaris. Diketahui bahwa semakin naiknya tingkat konsentrasi zat pengaktivasi (activator agent) akan menyebabkan rendemen karbon aktif yang diperoleh menurun. Rendemen tertinggi diperoleh sebanyak 48.64\% dan rendemen terendah diperoleh sebanyak $27.60 \%$. Penurunan ini terjadi karena reaksi yang terjadi antara zat pengaktivasi dengan unsur-unsur yang terdapat dalam arang mikroalga. Reaksi yang terjadi secara umum adalah reaksi pemutusan molekul karbon dan penghilangan deposit hidrokarbon dan beberapa mineral yang terdapat pada arang microalga Chlorella vulgaris sebelum terjadinya reaksi aktivasi. Reaksi aktivasi ini berdampak pada penyusutan massa antara arang sebelum proses aktivasi dan setelah proses aktivasi, maka dari itu rendemen dari karbon aktif hasil aktivasi dapat berkurang.

\subsection{Kadar Abu}

Analisis kadar abu pada karbon aktif bertujuan untuk mengetahui kandungan abu di dalam karbon aktif. Kadar abu diindikasikan sebagai sisa mineral dan oksida logam yang masih tertinggal selama proses karbonisasi, karena biomassa atau bahan alam yang digunakan sebagai bahan baku karbon aktif tidak hanya mengandung unsur karbon tetapi juga mengandung unsur mineral dan oksida.

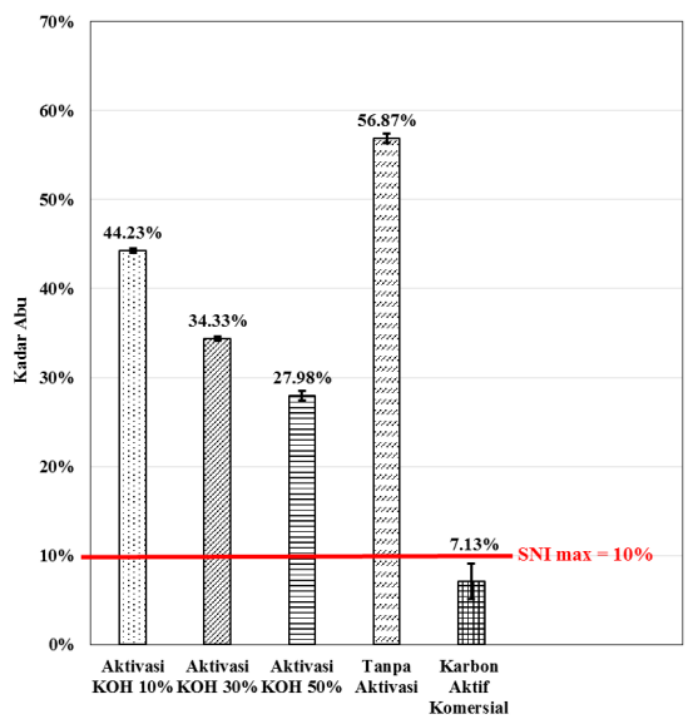


Gambar 2. Kadar abu karbon aktif mikroalga Chlorella vulgaris masih cukup tinggi dibandingkan karbon aktif komersial.

Dari Gambar 2 dapat diketahui bahwa dengan semakin bertambahnya konsentrasi zat pengaktivasi cenderung dapat mengurangi kadar abu karbon aktif. Kadar abu karbon aktif mikroalga Chlorella vulgaris semakin menurun hingga sebesar 27,98\% dibandingkan arang mikroalga yang tidak diaktivasi (tanpa perlakuan) yaitu sebesar 56.87\%. Kadar abu terendah dan yang sesuai dengan SNI sebesar 7,13\% dicapai oleh karbon aktif komersial yang berbahan dasar tempurung kelapa yang diaktivasi dengan menggunakan uap air pada suhu tinggi. Faktor bahan baku ini menjadi faktor utama nilai kadar abu karbon aktif mikroalga yang masih belum sesuai dengan standar SNI (yaitu maksimal 10\%), karena mikroalga mengandung banyak komponen yang dapat menyebabkan terbentuknya abu. Tingginya kadar garam dari bahan baku mikroalga Chlorella vulgaris juga memberikan kontribusi pada tingginya kadar abu karbon aktif yang dihasilkan. Hal lain yang juga mempengaruhi tingginya kadar abu adalah proses karbonisasi yang mungkin belum sempurna dengan adanya kontak sampel dengan udara yang menyebabkan terbentuknya abu dalam jumlah yang lebih besar.

\subsection{Kadar Zat Teruap}

Kadar zat teruap pada karbon aktif mengindikasikan penguapan unsur dan senyawa non karbon. Kadar zat yang menguap merupakan hasil dekomposisi unsur-unsur penyusun karbon aktif akibat proses pemanasan selama proses karbonisasi dan aktivasi.

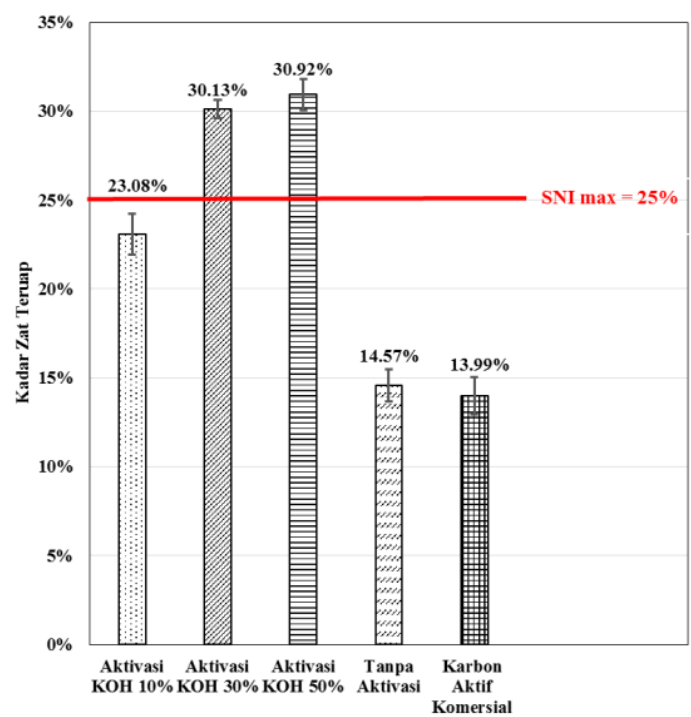

Gambar 3. Kadar zat teruap karbon aktif mikroalga Chlorella vulgaris dibandingkan dengan karbon aktif tempurung kelapa.

Gambar 3 menyajikan hasil dari perhitungan kadar zat teruap karbon aktif mikroalga Chlorella vulgaris. Diketahui bahwa dua perlakuan yang masih belum memenuhi SNI kadar zat teruap karbon aktif (yaitu maksimal 25\%). Dua perlakuan yang belum memenuhi standar tersebut adalah karbon aktif dengan

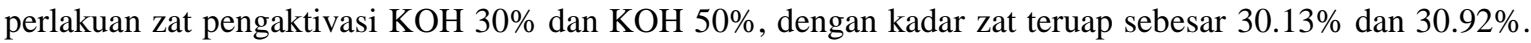
Terjadinya kenaikan kadar zat teruap pada konsentrasi yang lebih tinggi disebabkan karena terjadinya pembentukan mikropori yang lebih banyak pada perlakuan aktivasi dengan menggunakan $\mathrm{KOH}$ pada konsentrasi 30 dan 50\% dibandingkan dengan $\mathrm{KOH}$ konsentrasi 10\%. Diduga mikropori yang terbentuk menyerap komponen-komponen zat folatil yang mudah menguap karena proses penyimpanan yang kurang kedap udara, hal inilah yang menyebabkan kenaikan kadar zat teruapnya menjadi semakin tinggi.

\subsection{Kadar Karbon Aktif Murni}

Kadar karbon aktif murni merupakan kadar karbon (C) yang terikat di dalam karbon aktif selain fraksi abu, zat menguap dan air. Kadar karbon terikat yang diperoleh dari karbon aktif mikroalga dari setiap perlakuan berkisan antara $27.55 \%-39.10 \%$. Kandungan karbon terikat tersebut dipengaruhi oleh kandungan dari kadar abu dan zat teruap yang terdapat dalam karbon aktif mikroalga Chlorella vulgaris. 


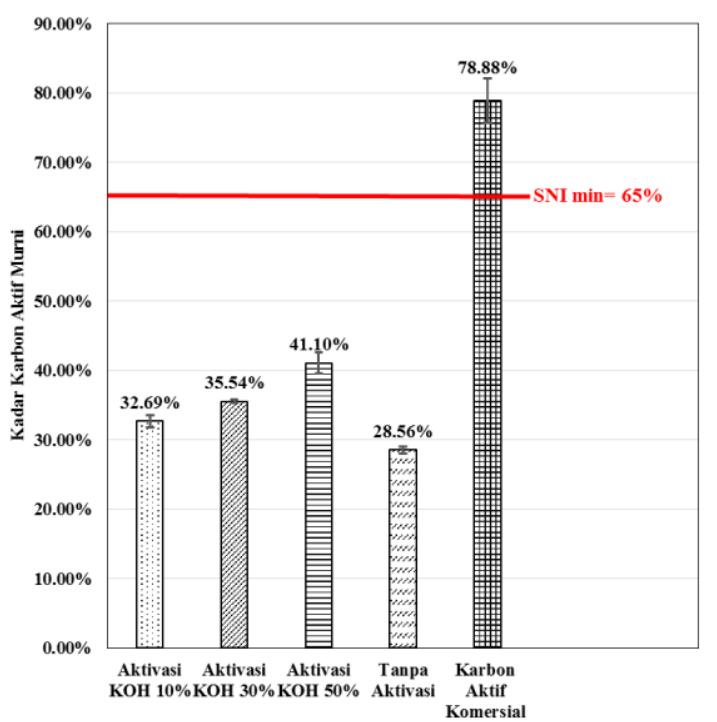

Gambar 4. Kadar karbon aktif murni mikroalga Chlorella vulgaris dibandingkan karbon aktif tempurung kelapa.

Dari Gambar 4 diketahui bahwa aktivasi yang telah dilakukan dapat meningkatkan kandungan karbon mikroalga Chlorella vulgaris, walaupun kenaikannya tidak signifikan. Bertambahnya nilai kadar karbon aktif murni meningkat dari arang mikroalga yang tidak diaktivasi sebesar $28.56 \%$, menjadi $32.69 \%, 35.54 \%$ dan 41.10\% ketika dilakukan aktivasi dengan konsentrasi $\mathrm{KOH}$ yang meningkat dari 10\%, 30\% hingga 50\%. Hanya saja, semua kandungan karbon aktif murni baik sebelum dan setelah aktivasi dalam penelitian ini masih dibawah standar SNI yang ditentukan yaitu minimal sebesar 65\%. Kandungan karbon ini sangat dipengaruhi oleh bahan baku awal yaitu serbuk mikroalga kering dimana diketahui bahwa sampel awal memiliki kandungan unsur karbon yang kecil. Hal ini memberikan pengaruh kepada kandungan karbon aktif murni mikroalga Chlorella vulgaris yang tidak jauh berbeda dengan persentasi unsur karbon bahan baku mikroalga Chlorella vulgaris setelah aktivasi.

\subsection{Daya Serap lodin}

Pengujian daya serap iodin dimaksudkan untuk mengetahui kemampuan karbon aktif dalam menyerap zat lain, khususnya zat cair. Hal ini sangat penting diukur untuk mengevaluasi kemampuan karbon aktif mikroalga sebagai absorber. Daya serap terhadap larutan iodin karbon aktif mikroalga hasil aktivasi kimia berbantukan gelombang mikro berkisar antara 189.46 sampai dengan $260.23 \mathrm{mg} / \mathrm{g}$. Daya serap terhadap larutan iodin ini dipengaruhi oleh kandungan karbon aktif murni dan terciptanya pori pada permukaan karbon aktif.

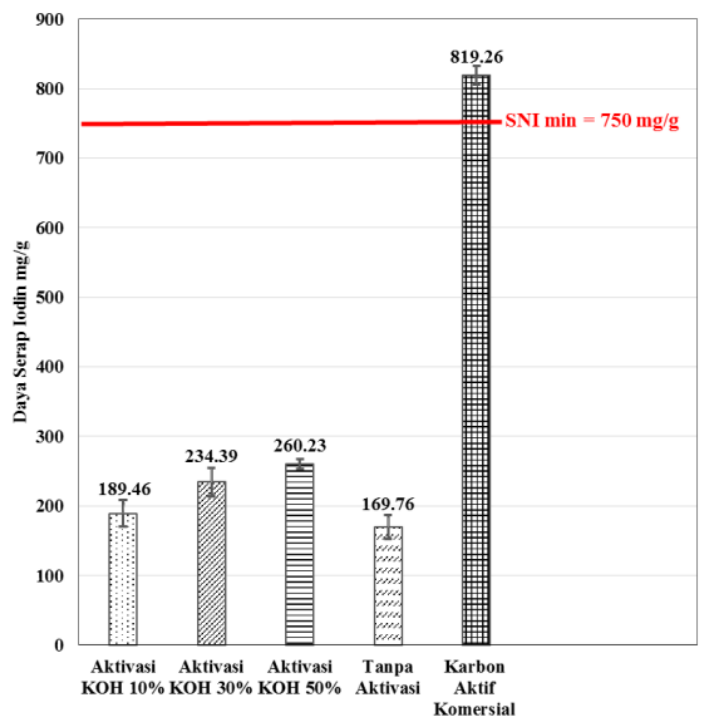


Gambar 5. Daya serap iodin karbon aktif mikroalga Chlorella vulgaris dibandingkan karbon aktif tempurung kelapa

Dari Gambar 5 dapat dilihat bahwa aktivasi yang dilakukan dapat meningkatkan daya serap karbon aktif mikroalga Chlorella vulgaris terhadap larutan iodin. Dapat dilihat bahwa daya serap iodin meningkat dari sampel yang tidak diaktivasi sebesar $169.76 \mathrm{mg} / \mathrm{g}$ dibandingkan dengan perlakuan aktivasi $\mathrm{KOH}$ berbantukan iradiasi gelombang mikro yaitu sebesar maksimal $260.23 \mathrm{mg} / \mathrm{g}$. Semua kandungan karbon aktif murni baik sebelum dan setelah aktivasi dalam penelitian ini masih dibawah standar SNI yang ditentukan yaitu sebesar minimum $750 \mathrm{mg} / \mathrm{g}$. Salah satu penyebab rendahnya daya serap iodin karbon aktif hasil aktivasi adalah, banyaknya kadar abu dan zat teruap dan kandungan unsur karbon yang sedikit, sehingga kandungan bahan pengotor yang banyak tersebut cenderung menutupi pori-pori karbon aktif yang terbentuk sehingga dapat menurunkan kemampuan karbon aktif dalam penyerapan zat warna.

\subsection{Analisis Pori Karbon Aktif Chlorella vulgaris}

Pengujian luas permukaan BET dilakukan terhadap sampel yang memiliki daya serap iodin tertinggi yaitu pada karbon aktif dengan aktivasi kimia dengan menggunakan $\mathrm{KOH}$ dengan konsentrasi 50\%. Dengan asumsi bahwa semakin tiggi daya serap iodin menandakan bahwa karbon aktif tersebut memiliki luas permukaan BET yang semakin besar. Hasil analisis dengan SAA menunjukkan bahwa karbon aktif mikroalga dengan daya serap iodin $260.23 \mathrm{mg} / \mathrm{g}$ ada pengujian iodin memiliki luas permukaan $34.933 \mathrm{~m}^{2} / \mathrm{g}$, dengan rata-rata diameter pori sebesar $46.59 \mathrm{~nm}$.

\subsection{Pencitraan SEM-EDX Karbon Aktif Chlorella vulgaris}

Pencitraan dengan menggunakan SEM-EDX dilakukan terhadap sampel karbon dengan daya serap iodin tertinggi, yaitu pada perlakuan aktivasi dengan menggunakan $\mathrm{KOH} 50 \%$. Pencitraan SEM-EDX juga dilakukan terhadap sampel mikroalga kering, arang mikroalga dan karbon aktif komersial sebagai pembanding.

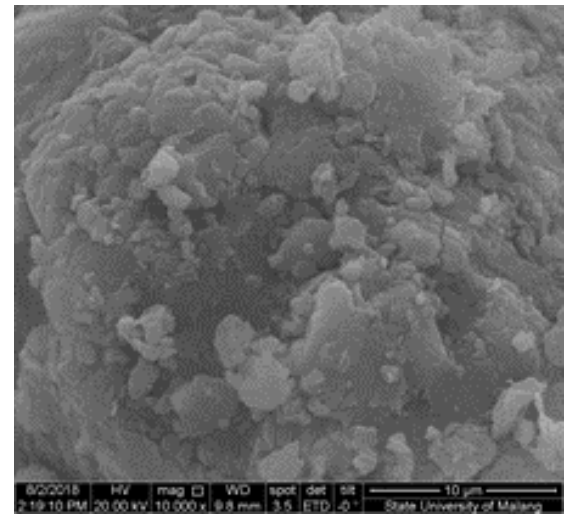

c.

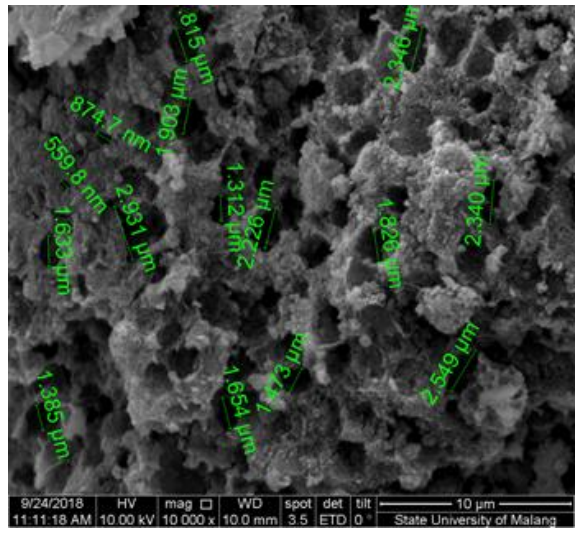

b.

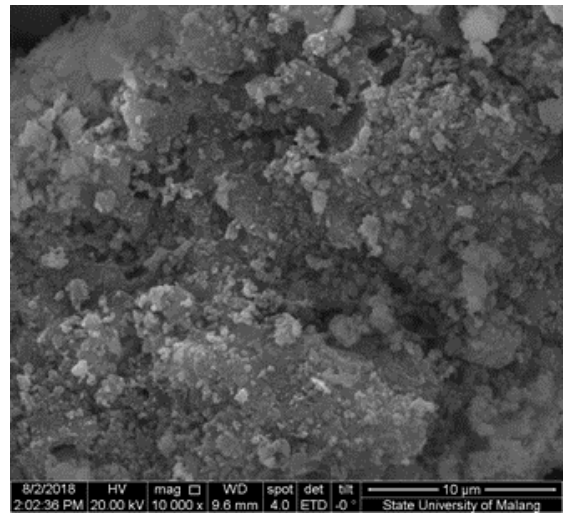

d.

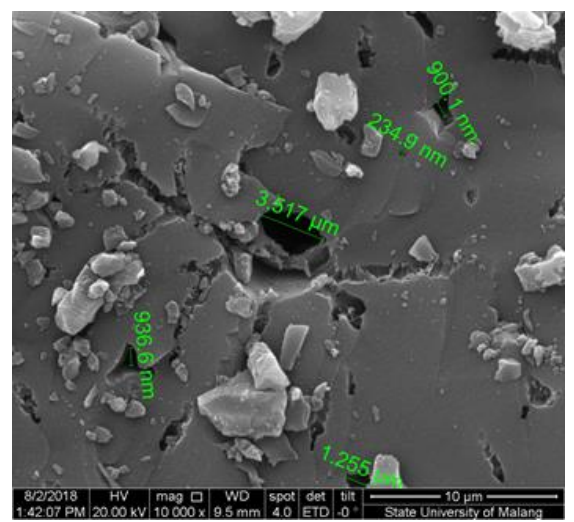

Gambar 6. Citra SEM EDX ;a. Serbuk mikroalga kering; b. Arang mikroalga; c.Karbon aktif hasil aktivasi dengan $\mathrm{KOH} 50 \%$; d.Karbon aktif komersial dari tempurung kelapa.

Dari hasil pencitraan SEM-EDX pada Gambar 6, dapat dilihat bahwa secara umum struktur dari serbuk mikroalga kering dan arang hasil karbonisasi dengan menggunkana suhu $500^{\circ} \mathrm{C}$ selama 30 menit 
menunjukan struktur yang hampir sama, yaitu sturktur berbentuk seperti gumpalan tanpa terbentuk mikropori dipermukaan. Berbeda dengan karbon aktif hasil aktivasi dengan $\mathrm{KOH} \mathrm{50 \%} \mathrm{yang} \mathrm{sudah} \mathrm{mulai} \mathrm{menunjukan}$ terbentuknya mikropori, namun karbon aktif ini masih memiliki zat pengotor yang cukup banyak. Tampilan zat pengotor ditunjukan dengan adanya butiran-bitiran halus yang menyelimuti permukaan pori yang terbentuk, hal ini berbeda dengan tampilan karbon aktif komersial yang terbuat dari batok kelapa dan telah memenuhi SNI yang menunjukan mikropori dan nanopori dengan permukaan yang lebih bersih. Adanya pengetor yang menyelimuti pori-pori karbon aktif ini, diduga memberikan peran penting dalam penyerapan iodin dan luas permukaan BET, hingga didapatkan hasil yang lebih kecil dibandingkan dengan karbon aktif komersial.

Table 1: Komposisi Unsur Serbuk, Arang dan Karbon Aktif Mikroalga dibandingkan dengan Karbon Aktif Komersial

\begin{tabular}{c|c|c|c|c}
\hline \multirow{2}{*}{ Unsur } & \multicolumn{4}{|c}{ Wt\% (persen berat) } \\
\cline { 2 - 5 } & Serbuk Mikroalga & Arang mikroalga & $\begin{array}{c}\text { Karbon Aktif } \\
\text { Mikroalga } \\
\text { (Aktivasi KOH 50\%) }\end{array}$ & $\begin{array}{c}\text { Karbon } \\
\text { Aktif } \\
\text { Komersial }\end{array}$ \\
\hline $\mathrm{C}$ & 16.09 & 27.81 & 26.24 & 87.18 \\
\hline $\mathrm{O}$ & 25.78 & 28.54 & 31.42 & 8.01 \\
\hline $\mathrm{Na}$ & 15.99 & 8.42 & - & 1.61 \\
\hline $\mathrm{Mg}$ & 14.24 & 15.63 & 21.97 & 0.20 \\
\hline $\mathrm{P}$ & 0.60 & 0.59 & 3.32 & - \\
\hline $\mathrm{Cl}$ & 23.87 & 15.55 & 0.64 & - \\
\hline $\mathrm{Ca}$ & 1.64 & 2.10 & 5.26 & - \\
\hline $\mathrm{Zr}$ & 1.03 & 1.36 & 3.59 & - \\
\hline $\mathrm{Si}$ & 0.18 & - & 2.02 & \\
\hline $\mathrm{S}$ & 0.58 & - & 0.16 & \\
\hline $\mathrm{Au}$ & & & 5.61 & \\
\hline
\end{tabular}

Tabel 1 menyajikan komposisi unsur penyusun dari mikroalga chlorella vulgaris kering sebagai bahan baku utama, arang mikroalga, dan arang hasil aktivasi dengan perlakuan terbaik yaitu aktivasi dengan menggunakan $\mathrm{KOH} 50 \%$. Dari tabel 1 dapat diamati bahwa selama terjadinya proses karbonisasi cenderung meningkatkan kandungan unsur karbon yaitu mengalami kenaikan dari $16.09 \%$ menjadi $27.81 \%$, hal ini karena proses karbonisasi dengan suhu tinggi telah menghilangkan sebagian unsur yang terdapat dalam biomassa chlorella vulgaris. Adanya proses aktivasi juga tidak menyebabkan kenaikan unsur karbon menjadi semakin tinggi, hal ini diduga karena reaksi kompleks yang terjadi selama aktivasi melibatkan raksi dengan unsur selain karbon sehingga proses aktivasi yang sebenarnya bertujuan untuk memecahkan struktukur karbon dan membersihkan deposit hidrokarbon tidak dapat berlangsung dengan kehadiran unsur-unsur ini. Dengan kandungan unsur yang dimiliki, terutama unsur karbon yang cukup sedikti membuat karbon aktif mikroalga memiliki struktur rapuh dan mudah hancur. Berbeda dengan karbon aktif komersial yang terbuat dari batok kelapa yang telah memenuhi SNI, dimana karbon aktif ini memiliki kandungan unsur karbon yang sangat tinggi yaitu mencapai 87.18\% dan dengan unsur-unsur lain selain karbon yang sangat sedikit, sehingga membuat karbon aktif ini memiliki struktur yang keras dan pori-pori permukaan yang bersih.

\section{KESIMPULAN}

Mikroalga Chlorella vulgaris memiliki kandungan unsur karbon yang berpotensi sebagai bahan baku karbon aktif walaupun dalam jumlah yang sedikit yaitu 16.09\%. Proses aktivasi menggunakan zat pengaktivasi $\mathrm{KOH}$ berbantukan iradiasi gelombang mikro mampu meningkatkan kadar karbon aktif Chlorella vulgaris yang besarnya mencapai $26.24 \%$ berat molekul dan daya serap iodin $260.23 \mathrm{mg} / \mathrm{g}$. Karbon aktif yang dihasilkan memiliki luas permukaan sebesar $34.933 \mathrm{~m}^{2} / \mathrm{g}$, dengan rata-rata pori $46.59 \mathrm{~nm}$. Akumulasi zat pengotor menjadi faktor utama karakteristik karbon aktif mikroalga masih belum memenuhi standar SNI, sehingga proses pra-pengolahan untuk pengurangan zat pengotor menjadi penting dilakukan pada penelitian selanjutnya. 


\section{PERNYATAAN TERIMAKASIH}

Penulis mengucapkan terimakasih kepada Lembaga Pengelola Dana Pendidikan (LPDP) atas bantuan dana penelitian tesis magister ini.

\section{DAFTAR PUSTAKA}

[1] WIBISONO, Y., Biomaterial dan Bioproduk, UB Press, Malang, 2017.

[2] BROWN, R.C., BROWN, T.R., Biorenewable Resources - Engineering New Products from Agriculture (second ed). Oxford UK: John Wiley \& Sons, 2014.

[3] DEVIANTO, L.A., APRILIA, D.N., INDRIANI D.W., SUKARNI, S., SUMARLAN, S.H., WIBISONO, Y., "Marine microalgae Nannochloropsis oculata biomass harvesting using ultrafiltration in cross-flow mode", In: IOP Conference Series: Earth and Environmental Science, 131 (1), 012042, 2018.

[4] YAN, C., ZHU, L., WANG, Y., "Photosynthetic CO2 uptake by microalgae for biogas upgrading and simultaneously biogas slurry decontamination by using of microalgae photobioreactor under various light wavelengths, light intensities, and photoperiods", Applied Energy, v. 178, pp. 9-18, Sept. 2016.

[5] CHEAH, W.Y., SHOW, P.L., CHANG, J.S., LING, T.C., JUAN, J.C.,"Biosequestration ofatmospheric $\mathrm{CO} 2$ and flue gas-containing $\mathrm{CO}_{2}$ by microalgae", Bioresource Technology, v.184, pp. 190-201, May 2015.

[6] JIANG, L., LUO, S., FAN, X., YANG, Z., GUO, R., "Biomass and lipid production ofmarine microalgae using municipal wastewater and high concentration of $\mathrm{CO}_{2}$ ", Applied Energy, v.88, pp. 3336-3341, Oct. 2011.

[7] VANTHOOR-KOOPMANS, M., WIJFFELS, R.H., BARBOSA, M.J., EPPINK, M.H.M., "Biorefinery of microalgae for food and fuel", Bioresource Technology, v.135, pp. 142-149, May 2013.

[8] YEN, H.W., HU, I.C., CHEN, C.Y., HO, S.H. LEE, D.J., CHANG, J.S., "Microalgae-based biorefinery - From biofuels to natural products", Bioresource Technology, v.135, pp. 166-174, May 2013.

[9] ZHU, Y., ALBRECHT, K.O., ELLIOTT, D.C., HALLEN, R.T., JONES, S.B., "Development of hydrothermal liquefaction and upgrading technologies for lipid-extracted algae conversion to liquid fuels", Algal Research, v.2, pp. 455-464, Oct. 2013.

[10] WANG, K., BROWN, R.C., HOMSY, S., MARTINEZ, L., SIDHU, S.S., "Fast pyrolysis of microalgae remnants in a fluidized bed reactor for bio-oil and biochar production", Bioresource Technology, v.127, pp. 494-499, Jan. 2013.

[11] ALZATE, M.E., MUNOZ, R., ROGALlA, F., FDZ-POLANCO, F., PEREZ-ELVIRA, S.I., "Biochemical methan potential of microalgae biomass after lipid extraction", Chemical Engineering journal, v.243, pp. 405-410, May 2014.

[12] CHENG, J., HUANG, R., YU, T., LI, T., ZHOU, J., CEN, K., "Biodiesel production from lipids in wet microalgae with microwave irradiation and bio-crude production from algal residue through hydrothermal liquefaction", Bioresource Technology, v.151, pp. 415-418, Jan. 2014.

[13] RAMOS-SUAREZ, J.L., CARRERAS, N., "Use of microalgae residues for biogas production", Chemical Engineering Journal, v.242, pp. 86-95, Apr. 2014.

[14] WIBISONO, Y., SUCIPTO, S., PERDANI, C.G., ASTUTI, R., DAHLAN, M., "Halal compliance on drinking water industries: a future perspective", In: Proceeding of the 3rd International Halal Conference (INHAC2016), pp.555 - 564, Springer, Singapore, Feb. 2018.

[15] PRATIWI, M.K., MASYRIFAH, L., HAWA L.C., DEWI, S.R., IZZA, N., ARGO, B.D., SUCIPTO, S., WIBISONO, Y. "Enhanced antibiofouling properties of chitosan-based membranes by coating and blending of Moringa oleifera L extract”, In: IOP Conference Series: Material Science and Engineering, v.434 (1), $012191,2018$.

[16] DEWI, R., WARDANA, I.N.G., HAMIDI, N., "Pengaruh Daya Penyinaran Mikro Terhadap karakteristik Pembakaran Droplet Minyak Jarak Pagar”, Jurnal Rekayasa Mesin, v.3, pp. 305-316, 2012. 